Article

\title{
Investigation about the Impact of Tourism Development on a Water Conservation Area in Taiwan
}

\author{
Hsiao-Hsien Lin ${ }^{1, *}$, Sheng-Shyong Lee ${ }^{2}$, Yuan-Shing Perng ${ }^{3}$ and Shih-Tsung Yu ${ }^{1}$ \\ 1 Department of Environmental Engineering, Da-Yeh University, No.168, University Rd., Dacun, \\ Changhua 51591, Taiwan; yust@mail.dyu.edu.tw \\ 2 Department of Physical Education, National Pingtung University, No.4-18, Minsheng Rd., \\ Pingtung City, Pingtung County 90003, Taiwan; pesports@ms11.hinet.net \\ 3 Department of Forestry, National Chung Hsing University, No.145, Xingda Rd., South Dist., \\ Taichung City 402, Taiwan; ysperng@nchu.edu.tw \\ * Correspondence: chrishome12001@yahoo.com.tw; Tel.: +886-4-8511888
}

Received: 28 April 2018; Accepted: 26 June 2018; Published: 5 July 2018

\begin{abstract}
The current state of tourism development in a water conservation area of Taiwan was investigated from the perspective of different stakeholders. An analytical framework was constructed using grounded theory, whereas data collection was performed through field observations, questionnaire surveys, and semi-structured interviews. The 1290 questionnaire responses were analyzed via statistical methods and multi-perspective analysis. Stakeholder responses varied owing to differences in their interests, needs, and perception of the overall state of development. In the absence of clear policies and plans for each village around the water conservation area, the opinions of the stakeholders will diverge regarding labor and technical expertise, product features, village cohesion, the release of flora and fauna into the wild, tourism image, ecological damage, village transportation, and service quality.
\end{abstract}

Keywords: tourism development; impact perception; grounded theory; stakeholder

\section{Introduction}

Sun Moon Lake is located in the foothills of Taiwan's Central Mountain Range. The history of the lake extends over hundreds of years, as mentions of the lake have been found in writings from the Ming and Qing Dynasties. The Sun Moon Lake area is surrounded by mountains in all directions and is very rich in biodiversity and water resources. A number of villages, which are reliant on the lake's resources, have been established around the lake. The "921 earthquake" reshaped this region and caused a widespread depression that left its people bereft of the means to sustain themselves. After many years of planning and reconstruction by the government, however, Sun Moon Lake has become a multifunctional water conservation area. The lake now acts as an artificial catchment area for Taiwan, provides an avenue for civilian fisheries, and fulfills the power generation, irrigation, and domestic water needs of the people.

Tourism development refers to the utilization of cultural and natural resources in a rural region to provide relaxation to tourists and to broaden their horizons, while improving the social, economic, and environmental conditions of the region itself and of its residents. The development of tourism at Sun Moon Lake had, at its peak, brought in 826,683,137.28 US dollars' worth of business revenue [1]. However, during the process of this development, the competition for natural resources around the lake (at varying levels and degrees) to fulfill human needs has produced both positive and negative impacts on the local economy, society, and environment [2-9]. This has led to a large decrease in 
tourist numbers in recent years [10], as shown in Figure 1, which is a potential crisis for the local government and residents, as well as tour operators in the area. For this reason, we have conducted an investigation on the current state of tourism development in the Sun Moon Lake area, to understand its developmental context and the root causes of its problems.
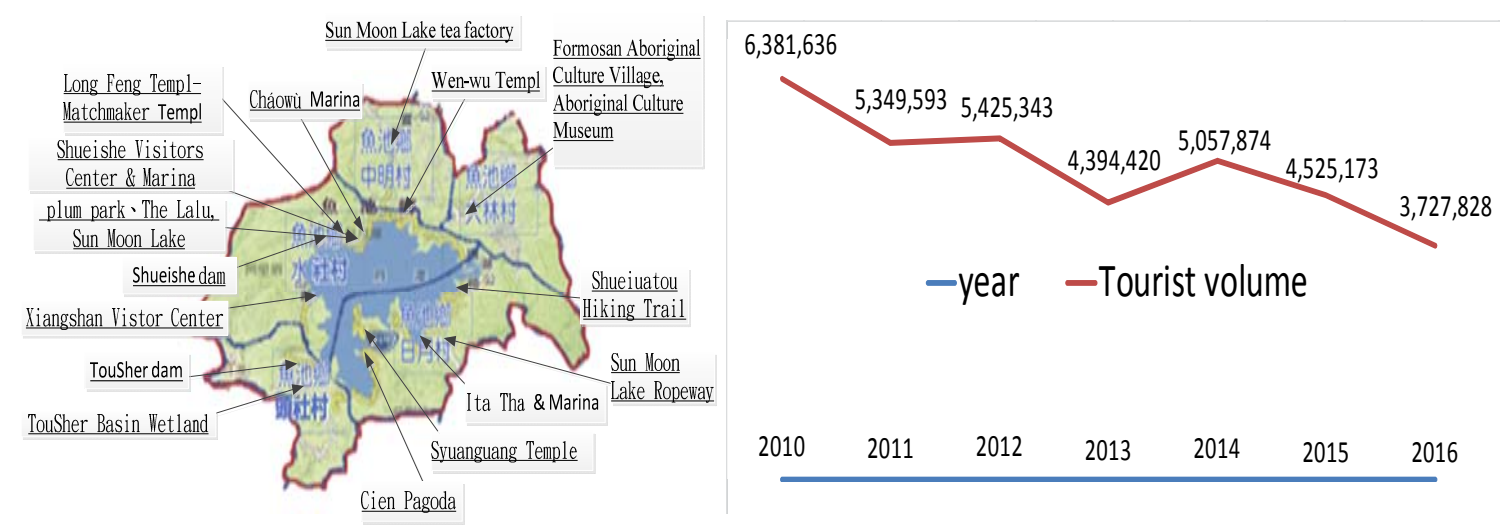

Figure 1. Illustrations of tourist attractions in the Sun Moon Lake region and the annual volume of visitors to the lake.

The original intention of tourism development is to counteract increases in stress caused by rapid advances in technology and transportation and the greatly accelerated pace of life, by providing a means for rest and relaxation. Although tourism development produces economic benefits, beautifies local communities, and improves basic infrastructure [9,11,12], negative impacts are often caused by overdevelopment [13]. Hence, tourism development without sustainability considerations usually results in net losses [11]. To solve the problems of tourism development, investigations have been conducted since 1970 on the effects of tourism development from the perspective of local residents $[5,6,14,15]$. Because tourism is based on the provision of travel experiences to tourists, in some later studies, local phenomena have also investigated tourist perceptions and feelings [16,17]. However, development is an issue that is based on interactions between humankind and the natural environment, and the purpose of development is to satisfy the economic, social, and environmental needs of residents and tourists alike. Therefore, the impacts of tourism development should not be investigated solely from the perspectives of local residents or tourists, as it is necessary to consider the behaviors and feelings of all participants in the activity to gain an understanding of the observed phenomena [18,19]. Although comparative studies have been conducted more recently [16,20,21], the majority of studies in this field are still being performed from the perspective of one side or the other [22]. Namely, none of those literatures discuss the impact of tourism development from the multiple perspectives. Therefore, in this study, the investigation of the impact of tourism development is taken consideration, from the perspectives of local residents, tourists, and other related participants to find the equilibrium in such impacts of tourism development. Based on that, the more beneficial strategies and managements are presented in this thesis.

The effects of tourism development on tourists and residents can be framed from the perspectives of supply and demand: a tourist destination provides the environment for sightseeing and travel, while the residents help to improve tourist activities, thus allowing the tourists to have an enjoyable sightseeing experience. Tourist visitation, on the other hand, helps to improve the development of local communities and individuals by promoting economic growth. However, the concerns surrounding tourism development are not limited to the provision of leisure to tourists and the improvement of the local economy and living standards, as it is also necessary to respect the natural environment and the principles of environmental ethics [17]. Sustainable tourism development can only be achieved under the premise of a harmonious coexistence between humankind and nature [23]. Although residents and tourists play different roles in tourism development, both parties behave similarly in that they satisfy 
their basic needs, expectations, and demands by extracting resources from the natural environment and ecosystem, by altering or adapting to the local environment [23]. The effects of tourists and residents on the local environment vary by region [19], and changes in tourism development are also perceived differently by people with various identities and backgrounds [21,22]. Therefore, to understand the effects of tourism development in an area, it is necessary to examine the current state of development and the problems besetting the area from the perspectives of tourists and residents alike [24]. In the current study, we investigated the changes caused by tourism development through the perspectives of different stakeholders on the same issues, in each village around Sun Moon Lake [4,25]. Divergences in the perspectives of each stakeholder were examined, and the problems caused by tourism development were analyzed. The findings of this study will provide a comprehensive set of data for future tourism and policy developments in water conservation areas. In the remaining sections of the Introduction, we will briefly describe the location of Sun Moon Lake and its current state of tourism development, introduce the theoretical framework for analyzing the impacts of tourism, and review the results of other related studies.

\subsection{Location of Sun Moon Lake and Its Current State of Tourism Development}

Sun Moon Lake, which is the collective name for Sun Lake and Moon Lake, is situated in Taiwan's Central Mountain Range, as shown in Figure 2. Based on the area of this water source, it is Taiwan's largest semi-natural lake/hydropower reservoir. Coupling this with the abundance of natural resources in this location, it is fitting that multiple administrative regions and governing units are responsible for this area. The lake is circumscribed by Taiwan Provincial Highway No. 21 and Provincial Highway No. 21A and is located within the administrative region of Nantou County and Yuchih Township. The Sun Moon Lake National Area Administration also manages the development and management of tourism resources in the Sun Moon Lake area. The villages established around Sun Moon Lake include Chung Ming, Dalin, Shui-She, Ri-yue, and Toushe villages, which have a total population of 16,138 residents in 2016. Under the co-management of the local government and residents, the well-known scenic locations of the lake attract millions of tourists annually [10].

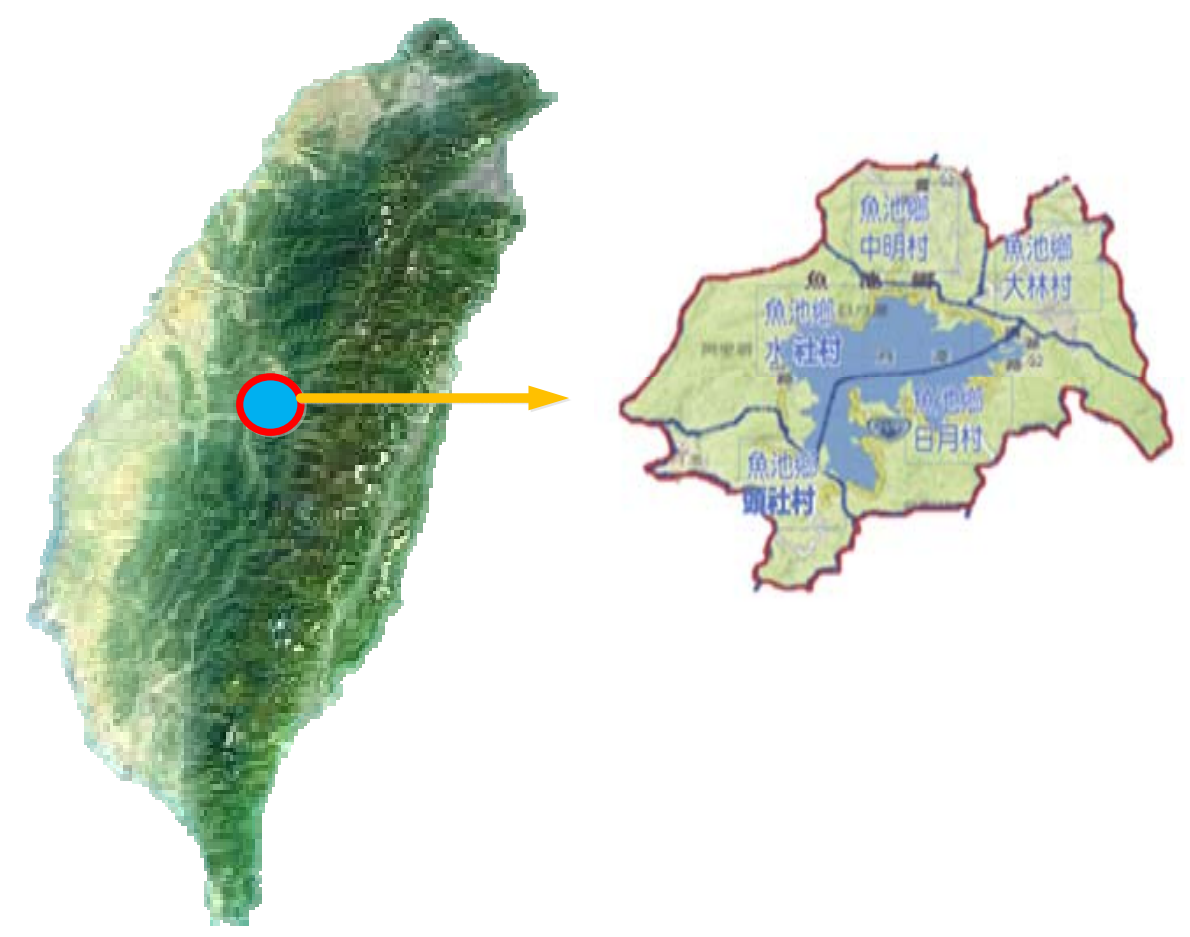

Figure 2. Location of Sun Moon Lake. 


\subsection{Theoretical Framework for Analyzing Tourism Impacts}

Tourism impacts may be categorized generally as economic, social, and environmental impacts, which may be further subdivided into 18 (e.g., Job opportunities) [9,11,12,25], 24 (e.g., Increased popularity of local areas) [6,9,11,12,25], and 25 (e.g., Community environment management) $[4,7,14,18,19,25]$ different issues, respectively. These issues were synthesized to produce an edited questionnaire about the impacts of tourism on Sun Moon Lake, as shown in Table 1.

Table 1. Constructs involved in the questionnaire on perceptions of the impact of tourism on Sun Moon Lake.

\begin{tabular}{|c|c|c|}
\hline Construct & Issues of Perceptions about the Impact of Tourism & Cronbach's $\alpha$ \\
\hline Economic (E) & $\begin{array}{l}\text { (E1) Job opportunities, (E2) Opportunities for starting a new business, } \\
\text { (E3) Earning a satisfactory wage, (E4) Higher living costs, (E5) } \\
\text { Tourism infrastructure, (E6) Tourism industry, (E7) Opportunities for } \\
\text { working as a tour guide, (E8) Integrating featured industries, (E9) } \\
\text { Opportunities for promoting tourism and leisure, (E10) Discounts on } \\
\text { the use of recreational facilities, (E11) Public infrastructure, (E12) } \\
\text { Contributions from industries, (E13) Higher prices of basic necessities } \\
\text { and housing, (E14) Healthcare, (E15) Channels of communication } \\
\text { with the government, (E16) Participation in policymaking, (E17) } \\
\text { Policies on tourism protection, (E18) Designing creative commodities. }\end{array}$ & $0.936-0.944$ \\
\hline Social (C) & $\begin{array}{l}\text { (C1) Increased popularity of local areas, (C2) Quality of tourism } \\
\text { services, (C3) Quality of tourism activities, (C4) Participation in } \\
\text { community development, (C5) Community maintenance, (C6) } \\
\text { Sufficient tourism indicators, (C7) Choice of recreational facilities, (C8) } \\
\text { More developmental associations, (C9) Attracting private businesses } \\
\text { with good performance, (C10) Young people returning home to start a } \\
\text { business or find work, (C11) Opportunities for vocational training, } \\
\text { (C12) Private businesses contributing to the local economy, (C13) } \\
\text { Living environment, (C14) Cultures and historical sites of significance } \\
\text { to indigenous people are preserved, (C15) Ability to self-manage, } \\
\text { (C16) Traditional cultural events, (C17) Excessive commercialization } \\
\text { due to tourism development, (C18) Tourists perceive that they are } \\
\text { trusted, (C19) Positive interactions between residents and tourists, } \\
\text { (C20) Contribution to the development of aboriginal cultural } \\
\text { industries, (C21) Safety management for tourism activities, (C22) The } \\
\text { number of police officers and firefighters, (C23) Sense of security in } \\
\text { daily life, (C24) Purchasing lands or properties. }\end{array}$ & $0.973-0.974$ \\
\hline $\begin{array}{l}\text { Environmental } \\
\text { (S) }\end{array}$ & $\begin{array}{l}\text { (S1) Community environment management, (S2) Promoting } \\
\text { environmental awareness, (S3) Preservation of historical sites, (S4) } \\
\text { Participation in local conservation work, (S5) Increased } \\
\text { environmental literacy among tourists, (S6) Well-planned tourist bus } \\
\text { routes, (S7) Consistent wireless Internet connectivity, (S8) } \\
\text { Comprehensive network of trails for walking and hiking, (S9) } \\
\text { Well-maintained cycling paths, (S10) Convenient public } \\
\text { transportation, (S11) The Internet makes life and work efficient, (S12) } \\
\text { Straightforward bike hire and management, (S13) Increased scale of } \\
\text { community facilities, (S14) Adequate parking spaces, (S15) Tourists } \\
\text { have an impact on the natural environment, (S16) Perceiving the } \\
\text { living space to be adequate, (S17) Convenient transportation to tourist } \\
\text { spots, (S18) Local water sources are polluted, (S19) Good air quality, } \\
\text { (S20) Lakes and rivers are polluted, (S21) Hillside overdevelopment, } \\
\text { (S22) Local ecological landscape is damaged, (S23) Excessive exhaust } \\
\text { fumes from cars and scooters, (S24) Increased noise and waste, (S25) } \\
\text { Invasion of foreign fish species }\end{array}$ & $0.926-0.927$ \\
\hline
\end{tabular}




\subsection{Analysis and Review of Related Studies}

The Earth's ecological environment provides an abundance of natural resources, sufficient to fulfill the needs of all life on the planet. Humankind, however, affects the natural environment to varying degrees in order to meet their needs for survival and living [11]. As different requirement levels result in varying levels of demand, the perceptions of each individual are the best indicator for ascertaining whether a resource is adequate for meeting the individual's needs [19].

The local residents of a tourist destination are the people who are most strongly affected by tourism development [5]. Several studies have been done on the impacts of tourism on local residents e.g., $[9,11,12,26,27]$, the results of which prove that the feelings of local residents towards the impacts of tourism development can vary significantly.

Tourists are the most important participants in and experiencers of tourism and travel [28]. Numerous tourist-based studies on tourism impacts have been conducted [23-31]; it was found that tourists also have varying opinions about the changes caused by tourism development.

Nonetheless, the ultimate result of tourism development is produced by interactions among residents, tourists, time, space, and the environment [7]. Residents leave their homes to develop their surrounding environment and make a living, so as to meet their living needs, whereas tourists travel through or temporarily stay in various locations for sightseeing purposes or to satisfy some other demand. Regardless of these differences, the behaviors and phenomena of tourists and residents alike are caused by the consumption of natural and cultural/historical resources to satisfy individual living needs and behavioral objectives.

The interaction between humankind and the environment will affect an area over the passage of time $[7,14]$. Therefore, a tourist area will be affected by interactions among residents, tourists, and the environment during the processes of tourism development. The perception of the effects associated with the current state of development will also differ according to the perspectives of each area $[25,32]$. Similarly, people with various identities or backgrounds will perceive the tourism development of an area differently [7]. Most studies on the impacts of tourism are performed only from the perspective of residents or tourists, rather than from both sides in parallel. By simultaneously obtaining information about the perceptions of tourists and residents on the state of development of a tourist area, it is then possible to observe differences between the perceptions of different stakeholders with respect to tourism development. This will useful for finding a balance between the views of tourists and residents. The findings of this work will therefore facilitate the formulation of objective and comprehensive tourism development plans and policies, in regions related to the study area.

\section{Methods and Instruments}

\subsection{Study Framework and Hypotheses}

In this study, the perceptions of different stakeholders regarding tourism development in the Sun Moon Lake region are discussed in order to propose suggestions for improvements in a manner that meets the expectations of residents and tourists. The implementation of a policy must be based on the consensus among residents, leaders, experts, and those who execute policy [24,33]. However, such issues are mostly discussed on a case-by-case basis, and residents and tourists have different opinions and needs. Thus, if different theories or methods are integrated to collect correct and reasonable data on residents' and tourists' opinions from different sources [34], and these data are compared with each other and evaluated [35], current tourism-related developments and policymaking regarding Sun Moon Lake can be adjusted in a manner that meets residents' and tourists' expectations.

The primary objective of this study was to explore the perceptions of residents and tourists about the current tourism developments in the Sun Moon Lake area and the impacts of these developments. Then, perceptions of residents from different villages in the scenic area and tourists were compared regarding current tourism developments. Finally, directions for the future development of local 
tourism in the Sun Moon Lake region and related suggestions were proposed. The study framework, based on the research objectives and relevant works reviewed, is provided in Figure 3.

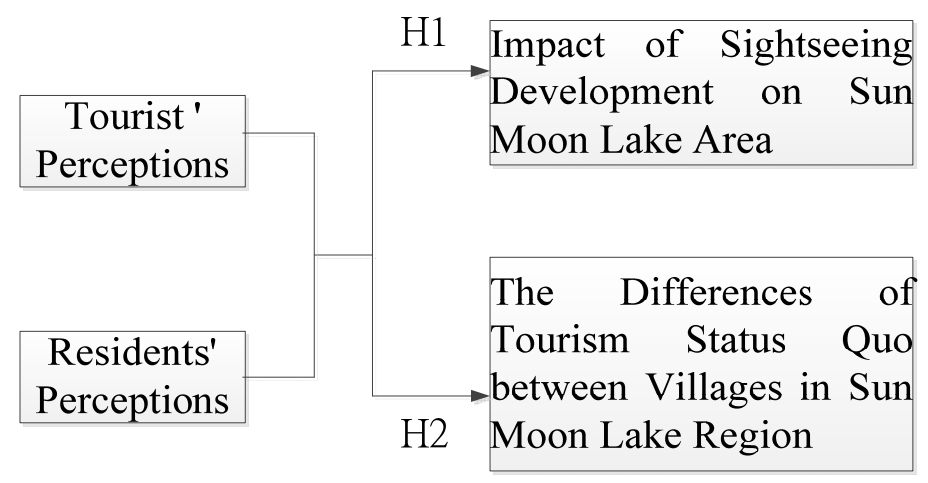

Figure 3. Study framework.

The study framework presents:

Hypotheses 1. There is a consistent perception about current tourism developments at Sun Moon Lake between residents and tourists.

Hypotheses 2. There is a consistent perception about current tourism developments at Sun Moon Lake between residents of various local villages and tourists.

\subsection{Study Procedure and Instruments}

The results of this study were interpreted according to the concepts of grounded theory [33-35], and the differences between tourists and residents were investigated through multi-perspective analysis. We first reviewed the relevant theories and literature, and then developed the questionnaire and interview outline through discussions with other experts and scholars. The field investigation and sampling in the study area were performed via random sampling, which resulted in the collection of 1290 valid responses. The SPSS for Windows 22.0 statistical package was used to collect all the sample data and statistically analyze each issue. Objective and realistic information was obtained through semi-structured interviews and open questions, which were designed to allow the interviewees to speak freely [36]. This research paper was drafted through a series of induction, organization, and analyses [33]. The research results, data sources, research theories, and methods were integrated via multi-perspective analysis, so as to facilitate the analysis of a diverse dataset from multiple perspectives and to compare the results of different studies [35,37]. In this way, accurate information was obtained on the current state of tourism development in the Sun Moon Lake region.

The questionnaire and the interview outline were developed based on relevant studies $[2-9,11,13]$ and a report on the overall tourism situation in the Sun Moon Lake region [38] and were used to explore current tourism developments at this destination. Both instruments were revised according to the results of an internal assessment that involved interviews with scholars, representatives of the Sun Moon Lake National Scenic Area Administration, representatives of the Tourism Bureau of Nantou County, and the chiefs of all villages in the scenic areas. Afterwards, the validity of the instruments was assessed to ensure optimal precision [39], as shown in Table 2. 
Table 2. Constructs involved in the questionnaire on perceptions of the impact of tourism on Sun Moon Lake and the interview outline.

\begin{tabular}{cl}
\hline No. & Interview Outline for the Perception of Current Tourism Developments at Sun Moon Lake \\
01 & $\begin{array}{l}\text { What is the biggest impact of increased job opportunities and industrial upgrading (E10, E11, E12, E14, } \\
\text { E15, E16, E17, and E18) on the local area? Please provide and explain two or more examples. }\end{array}$ \\
02 & $\begin{array}{l}\text { What is the biggest impact of policy promotion and implementation (E1, E2, E4, E5, E6, E7, and E8) on } \\
\text { the local area? Please provide two or more examples and briefly describe them. }\end{array}$ \\
\hline 03 & $\begin{array}{l}\text { What is the biggest impact of public infrastructure and increased wages (E3, E9, E11, and E13) on the } \\
\text { local area? Please provide two or more examples and briefly describe them. }\end{array}$ \\
\hline 04 & $\begin{array}{l}\text { What is the biggest impact of the improved quality of tourism development (C16, C17, C18, C19, C20, } \\
\text { C22, C23, and C24) on the local area? Please provide and describe two or more examples. }\end{array}$ \\
\hline 05 & $\begin{array}{l}\text { What is the biggest impact of industrial contributions to the community (C15, C16, C18, C19, C20, C21, } \\
\text { C22, C23, and C24) on the local area? Please provide and describe two or more examples. }\end{array}$ \\
06 & $\begin{array}{l}\text { What is the biggest impact of public security management and cultural preservation (C1, C2, C3, C4, C6, } \\
\text { C7, and C15) on the local area? Please provide two or more examples and briefly describe them. }\end{array}$ \\
\hline 07 & $\begin{array}{l}\text { What is the biggest impact of transportation services and Internet communication (S6, S7, S8, S9, S10, } \\
\text { S11, and S12) on the local area? Please provide two or more examples and briefly describe them. }\end{array}$ \\
\hline 08 & $\begin{array}{l}\text { What is the biggest impact of man-made pollution and environmental degradation (S20, S21, S22, S23, } \\
\text { S24, and S25) on the local area? Please provide two or more examples and briefly describe them. }\end{array}$ \\
\hline 09 & $\begin{array}{l}\text { What is the biggest impact of public participation in environmental conservation (S1, S2, S3, S4, and S5) } \\
\text { on the local area? Please provide two or more examples and briefly describe them. }\end{array}$ \\
\hline 10 & $\begin{array}{l}\text { What is the biggest impact of tourist facilities and services (S13, S14, S15, S16, and S17) on the local } \\
\text { environmental space? Please provide two or more examples and briefly describe them. }\end{array}$ \\
\hline $\begin{array}{l}\text { What is the biggest impact of air and water quality (S18 and S19) on the local area? Please provide two } \\
\text { or more examples and briefly describe them. }\end{array}$
\end{tabular}

\section{Analysis of Results}

Individuals express different opinions about current tourism developments [6,23]. Analyzing these opinions helps to elucidate their perceptions and needs regarding tourism developments in local areas [35,39]. By conducting such an analysis in a balanced manner, relevant answers can be obtained [40]. Grounded theory can be applied in combination with qualitative and quantitative methods to acquire the information necessary to analyze relevant issues $[33,36]$. Field investigation and sampling were performed via simple random sampling. In our investigation on the impacts of tourism development, a $t$-test was first performed to analyze the questionnaire responses. The results of the interviews were then collected and compared. Finally, a multi-perspective analysis was performed to compare and analyze the results of this study.

\subsection{Descriptive Characteristics of the Sample}

Descriptive statistics of the 1290 valid responses obtained through convenience sampling suggested that the majority of participants were tourists (67.7\%), female (51.5\%), and aged 21-30 years $(33.6 \% ; 20.2 \%$ were aged 20 years or younger) and held a Bachelor's degree $(43 \%)$. This sample was used as the basis for the quantitative analysis, as shown in Table 3.

All interviews were audio recorded and subsequently transcribed into textual data for analysis. The interviews were conducted with (a) residents who had lived in the environs of Sun Moon Lake for over 30 years; (b) local government officials; (c) tourists who had visited Sun Moon Lake two or more times in the past 3 years; and (d) 15 scholars with related academic backgrounds. Although the sample size was limited, participant inclusion criteria were rigorously designed. Therefore, the sample was representative and comprised reliable data that were obtained from different participant groups [26]. 
Table 3. Descriptive characteristics of the participants.

\begin{tabular}{|c|c|c|c|}
\hline \multicolumn{2}{|l|}{ Identity } & \multicolumn{2}{|l|}{ Gender } \\
\hline Residents & $35.3 \%$ & Male & $48.5 \%$ \\
\hline Tourists & $64.7 \%$ & Female & $51.5 \%$ \\
\hline \multicolumn{2}{|l|}{ Age } & \multicolumn{2}{|l|}{ Education Level } \\
\hline Under 20 & $20.2 \%$ & Elementary & $5.2 \%$ \\
\hline $21-30$ & $33.6 \%$ & Junior high school & $6.1 \%$ \\
\hline $31-40$ & $14.7 \%$ & High school & $21.7 \%$ \\
\hline $41-50$ & $11.9 \%$ & Academy & $19.5 \%$ \\
\hline $51-60$ & $8.0 \%$ & University & $43.0 \%$ \\
\hline Over 61 & $11.8 \%$ & Graduate School & $4.5 \%$ \\
\hline Local Government Official (G) & Resident (P) & Tourist (T) & \\
\hline G1 Chief of Dalin Village & P1 Mr. Lin & T1 University professor & \\
\hline G2 Chief of Ri-yue Village & P2 Ms. Guan & T2 University professor & \\
\hline G3 Chief of Chung-ming Village & P3 Ms. Lin & T3 Vocational high school teacher & \\
\hline G4 Chief of Shui-she Village & P4 Ms. Lai & T4 Vocational high school teacher & \\
\hline $\begin{array}{l}\text { G5 Chair of the Toushe Community } \\
\text { Development Association }\end{array}$ & P5 Ms. Lin & T5 Vocational high school teacher & \\
\hline $33.30 \%$ & $33.30 \%$ & $33.30 \%$ & \\
\hline
\end{tabular}

3.2. Perceptions of Different Stakeholders about Current Tourism Developments in the Sun Moon Lake Area and in Local Villages

The sustainable operation and development of tourism requires interactions between residents and tourists and their identification $[8,17,23,41,42]$. These parties differ in opinion but share the same needs [23]. Differences of opinion also occur among people from different backgrounds and places of residence $[19,21,22]$. Accordingly, in this study, current tourism developments in the Sun Moon Lake region and in local villages were examined from the perspectives of (a) individuals with different identities [19] and (b) different tourist destinations [6].

\subsubsection{Economic Development}

In the context of the overall economic development of the Sun Moon Lake area, there were significant differences between the perceptions of each stakeholder about tourism services, consumption choices, business investment, and job earnings $(p<0.001)$, as shown in Figure 4 (left). According to the interviewees, the provision of adequate sightseeing services and consumer choices will be sufficient to satisfy tourist needs. The residents hope that tourism-driven improvements in business investment and earnings will meet their expectations. If the living needs of the residents cannot be met, this will lead to a divergence between each stakeholder in their opinions about the following tourism-related economic issues: job opportunities, opportunities for starting a new business, opportunities for working as a tour guide, policies on tourism protection, and designing creative commodities [9,11,12,23-31].

In terms of the economic development of each village, significant differences were also present among the economic-development-related perceptions of the stakeholders, especially regarding tourism planning, healthcare, consumption choices, tourism infrastructure, and professional ethics $(p<0.001)$, as shown in Figure 4 (right). Further improvements in tourism planning, healthcare, and consumer choices will improve the attractiveness of the region for tourist consumption. It was also mentioned that certain areas of Sun Moon Lake have been developed in an unsound or excessive manner, in efforts to turn a profit from the tourism industry. The local residents and entrepreneurs would like to utilize the opportunities afforded by tourism in this region, but owing to a lack of supporting infrastructure and the absence of sustainable business concepts, the cost of living and housing prices have increased as a consequence. These issues have led to significant differences in 
opinion among the stakeholders in each village, concerning the following issues: opportunities for starting a new business, higher living costs, higher prices of basic necessities and housing, healthcare, policies on tourism protection, and designing creative commodities [9,11,12,23-31].

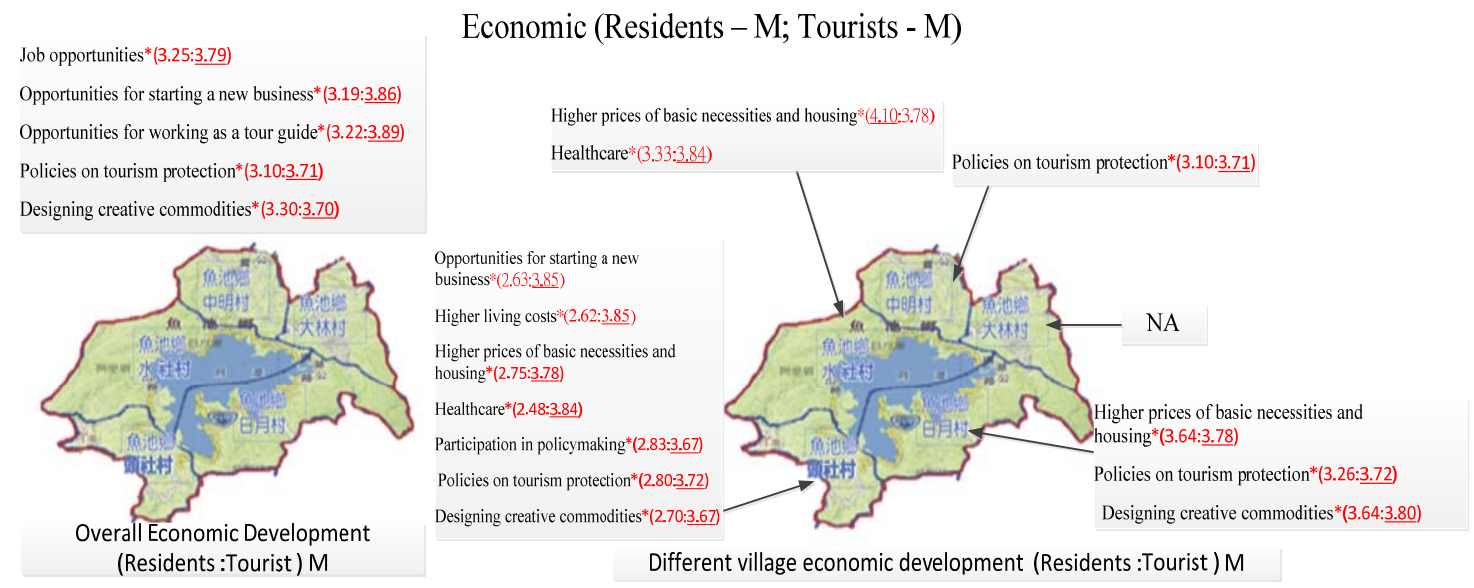

Figure 4. Distribution of the perceptions of residents and tourists about the economic impact of tourism development on Sun Moon Lake. Village $1=$ Chung-ming Village, Village $2=$ Dalin Village, Village $3=$ Shui-she Village, Village $4=$ Ri-yue Village, Village $5=$ Toushe Village; ${ }^{*} p<0.001$.

The impacts of tourism development on tourists and residents are also affected by the demands of each entity. In terms of the objectives of tourism development, tourism resources are meant to provide sightseeing opportunities and experiences for tourist consumption. Therefore, a tourist's desire to visit a certain destination could be reduced if reasonable levels of service quality or attractive specialty products cannot be provided. This affects the job and business opportunities of the residents and their hopes to improve their current financial state. Each stakeholder therefore perceives issues related to economic development differently. It is therefore necessary to simultaneously satisfy the psychological and physiological needs of tourists and residents alike to achieve the balance point in economic development.

Our recommendations are as follows: the quality of tourism services should be improved, and new products should be created to increase consumer options. New tourist commodities should also be created to increase job earnings. Each village should develop its own specialties, and regional sightseeing tours should be established. Healthcare facilities should be improved to enrich the quality of life. New specialty products and sightseeing activities should be created to increase consumer options. A tourism organization should be established to help manage the state of consumer consumption. Sustainable tourism should be promoted to increase public acceptance of this concept. The implementation of these suggestions will be important for improving the current state of economic development around Sun Moon Lake.

\subsubsection{Social Development}

In terms of the overall social development of the Sun Moon Lake area, significant differences were present in the perceptions of stakeholders about issues such as population structure, labor resources, space for development, quality of life, acceptance of tourism development, tourism infrastructure, and specialty development $(p<0.001)$, as shown in Figure 5 (left). The authorities and residents of the tourist areas have invested strongly in tourism development and infrastructure in order to provide the best possible service experiences and tourism infrastructure to the tourists. However, development of the area has been constrained by declining populations and a lack of professionalism in some places. As the residents also wish to preserve their quality of life and environment, they still hold certain reservations towards investments in tourism development. Although Sun Moon Lake 
has an abundance of tourist attractions and highly developed tourism infrastructure and planning in some areas of the lake, the tourists come from various locations worldwide, with highly diverse economies, infrastructures, and foods. If a tourist area is very similar to the place of residence of the tourists and has no distinguishing features, the travel experiences of tourists in the area will then be negatively affected. The aforementioned problems are responsible for differences in the perceptions of stakeholders towards the following issues: quality of tourism activities, participation in community development, sufficient tourism indicators, more development associations, attracting excellent private businesses, young people returning home to start a business or find work, opportunities for vocational training, living environment, traditional cultural events, tourists perceive that they are trusted, positive interactions between residents, and contribution to the development of aboriginal cultural industries $[9,11,12,23-31]$.

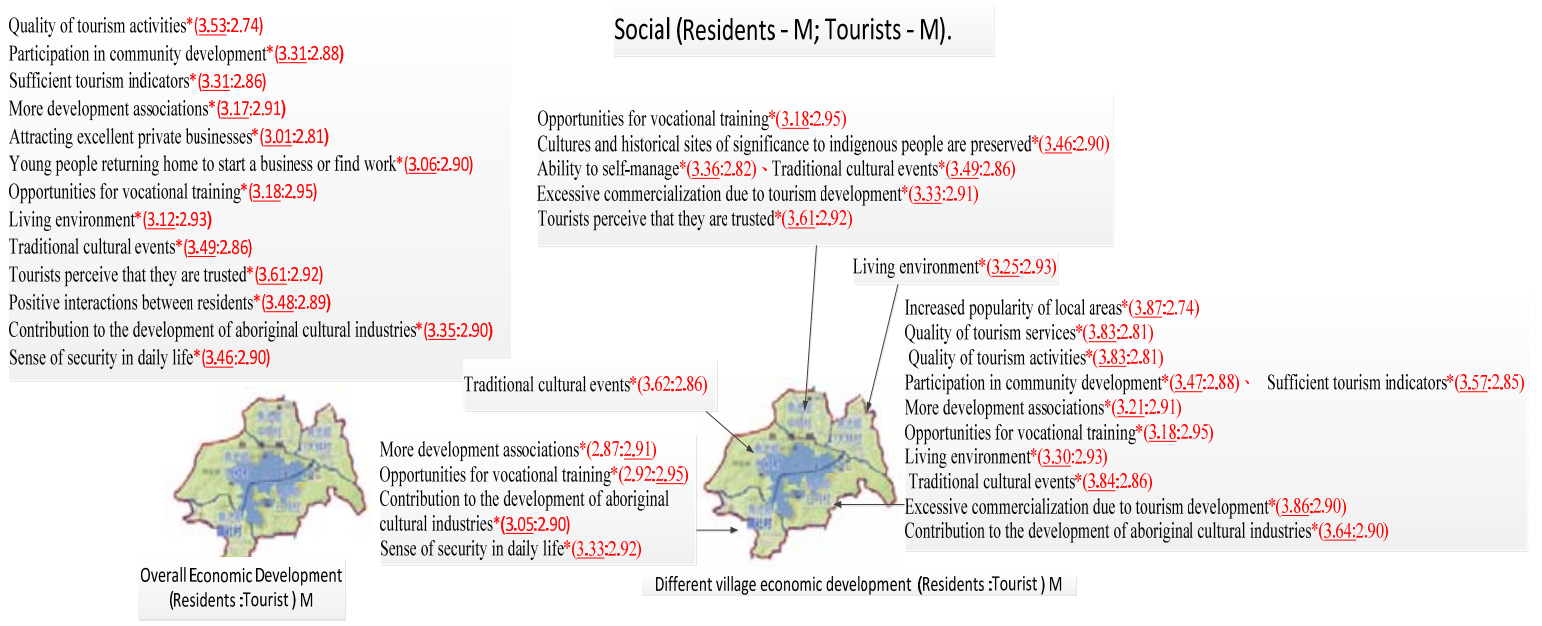

Figure 5. Distribution of the perceptions of residents and tourists about the social impact of tourism development on Sun Moon Lake. Village 1 = Chung-ming Village, Village $2=$ Dalin Village, Village $3=$ Shui-she Village, Village $4=$ Ri-yue Village, Village $5=$ Toushe Village; ${ }^{*} p<0.001$.

In the context of the social development of each village, there were significant differences between the perceptions of each stakeholder regarding population structure, labor resources, and tourism acceptance $(p<0.001)$, as shown in Figure 5 (right). Each village expects tourism development to improve their current state of social development. As long as a tourist area has the potential for further development, its residents will fully invest in the tourism industry. However, as the populations in the villages are aging, there is currently a lack of labor resources, which has resulted in disparities between the desired effect and implementation of tourism development policies. Although Sun Moon Lake is a well-known tourist destination in Taiwan that attracts millions of visitors each year and countless investors, the development strategies in each area of the lake are largely the same, which makes it difficult to distinguish the specialties of each village. Some scenic spots are relatively obscure owing to a lack of careful planning and development. Most of the local residents work in agriculture, but the aging of the population is now a serious problem. This problem is exacerbated by a lack of knowledge, expertise, and technological fluency, as well as the departure of young people from the region. In some locations, many buildings simply lie idle and unused. As the tourist areas are filled with outsiders who came for entrepreneurial purposes, the feeling of "localness" is generally absent in these areas. This has made it all but impossible for the tourists to get a feeling for the specialties and attractions of this region. The aforementioned problems have caused significant differences in the perceptions of the stakeholders in each village about the following issues: increased popularity of local areas, quality of tourism services, quality of tourism activities, participation in community development, sufficient tourism indicators, more development associations, attracting excellent private businesses, 
young people returning home to start a business or find work, and opportunities for vocational training $[9,11,12,23-31]$.

Differences in the cultural background and specialties of each village will lead to varying levels of differentiation in their buildings, histories, and cultures. The addition of enthusiasm from the residents and local customs and cultures will also help to improve the attractiveness of a village for tourism. Although the residents have invested significantly in tourism development, an insufficient supply of labor is available for driving these developments. Furthermore, the tourists are unable to perceive the growth of the community owing to issues such as an aging population, insufficient professional expertise, ambiguities in development plans, and development stagnation due to idle constructions. This has led to significant differences in the perceptions of stakeholders of social-development-related issues $[9,11,12,23-31]$.

Therefore, local tourism specialties should be developed according to the culture and specialties of each village. Creative industries and marketing concepts should be introduced based on currently existing industries in order to drive vocational training in the region, so as to improve the tourism-related expertise of the residents, increase their acceptance of tourism development, and encourage young people to return to their villages. These measures are necessary for the social development of this region.

\subsubsection{Environmental Development}

With regards to the overall environmental development of the Sun Moon Lake area, the perceptions of each stakeholder about issues such as illegally released flora and fauna, the planning of bicycle paths, public transportation for the villages, and water ecology differed significantly $(p<0.001)$, as shown in Figure 6 (left). According to the interviewees, the bicycle paths of the lake are world famous, and well-known bicycle entrepreneurs have invested in the development of these lakes. Further investments by the central government and local authorities in the transportation industry have produced a highly developed transportation system that is well equipped for meeting tourist needs. However, many tourists now feel that the lake ecosystem is under threat because of frequent news reports about illegal releases of flora and fauna into the lake. The bicycle paths are mainly constructed along the periphery of the lake, which is not beneficial for the development of villages around the lake. Furthermore, the concentration of public transportation access points in tourist areas has not improved the transportation woes of the local residents. The dramatic decline in the number of residents involved in the aquaculture industry has also reduced the sensitivity of local residents towards the ecological health of Sun Moon Lake. This has resulted in significant differences among the perceptions of the stakeholders in each village about the following issues: straightforward bike hire and management, perceiving the living space to be adequate, convenient transportation to tourist spots, and invasion of foreign fish species [9,11,12,23-31].

In the context of the environmental development of each village, there are also significant differences between the perceptions of each stakeholder about the ecological damage caused by foreign fish species, the price of local commodities, and population decline $(p<0.001)$, as shown in Figure 6 (right). According to the interviewees, Sun Moon Lake is blessed with a very special location and an abundance of natural and environmental resources. Furthermore, long-term tourism development has led to the establishment of various forms of public transportation, thus providing a plethora of transportation options for tourists. This has considerably improved the tourism and sightseeing environment of Sun Moon Lake. Tourists have become increasingly aware of the lake's ecological issues through the frequent reports of ecological damage caused by foreign fish species. Furthermore, the sharp decline in well-known local fishery products has increased the price of their related commodities. Residents engaged in the aquaculture industry are predominantly from indigenous tribes, whose young people are departing the region at alarming rates, which has destabilized the population structures of some villages. The elderly cannot contribute to the growth of tourism or aquaculture industries, as they are lacking in technical expertise and are unable to contribute effectively 
to the labor supply. Furthermore, the elderly also require a quiet living space. The planning of public transportation routes and bicycle paths that are useless for improving the development of local communities or solving their transportation woes exacerbates these issues. Consequently, there are significant differences in the perceptions of the stakeholders in each village about the following issues: promoting environmental awareness, well-planned tourist bus routes, convenient public transportation, straightforward bike hire and management, perceiving the living space to be adequate, (S17) convenient transportation to tourist spots, hillside overdevelopment, and invasion of foreign fish species $[9,11,12,23-31]$.

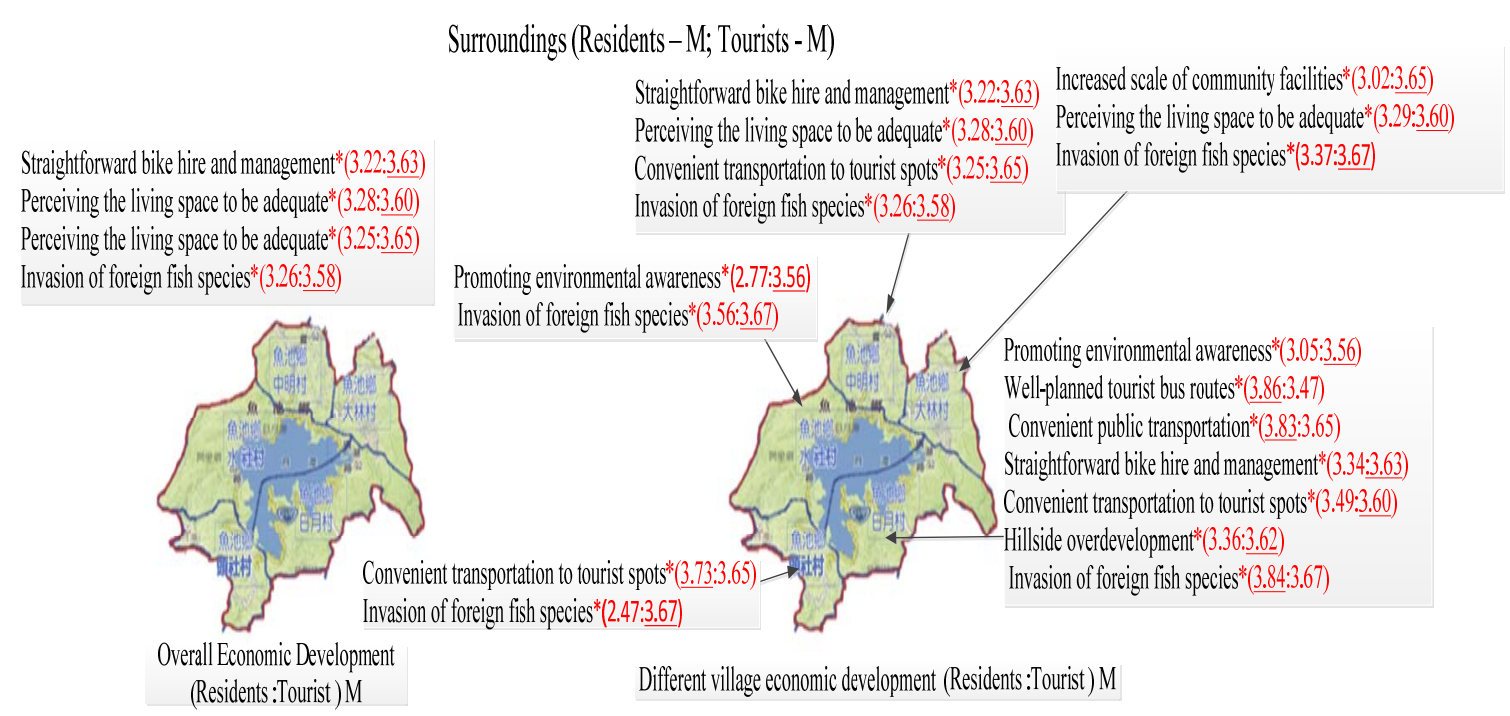

Figure 6. Distribution of the perceptions of residents and tourists about the environmental impact of tourism development on Sun Moon Lake. Village 1 = Chung-ming Village, Village $2=$ Dalin Village, Village 3 = Shui-she Village, Village $4=$ Ri-yue Village, Village $5=$ Toushe Village ${ }^{*} p<0.001$.

The basic concept of tourism development is to use the natural ecology and environmental resources of a location to develop various tourism facilities. Nonetheless, it is only possible to attract tourists if this development is coupled to the investment of local residents. Therefore, tourism development must be premised on the concept of sustainable development. It is critically important to halt illegal releases of flora/fauna and the destruction of water ecosystems to enable the propagation of a positive tourism image. The number of public transportation access points in the villages must also be increased. If these improvements are not implemented, the perceptions of each stakeholder about environmental-development-related issues will continue to diverge.

We recommend that the villages around the lake be linked to the lake's bicycle path, to increase the number of rest stops and scenic spots on the path. The number of public transportation access points in the villages should be increased to resolve the transportation woes of the residents and increase the visibility of the villages. Native fish species should be artificially farmed and the release of (native) fingerlings should be introduced. The number of residents working in the fishery industry should be increased, and ecological literacy should be promoted. Tourism-related water or fishery activities should be developed to increase tourist options. An environmentally friendly consumption environment should be promoted, to enable the implementation of sustainable tourism development.

\section{Conclusions and Recommendations}

\subsection{Conclusions}

In the Sun Moon Lake region as a whole, the economic-development-related issues with the most significant differences in stakeholder perception are tourism services, consumer choices, business 
investments, and job earnings. The corresponding social-development-related issues are population structure, labor resources, space for development, quality of life, acceptance of tourism development, tourism infrastructure, and specialty development. The environmental-development-related issues that exhibit the greatest divergence in stakeholder opinion are illegal releases of flora and fauna, the planning of bicycle paths, public transportation in villages, and the state of water ecosystems.

In our opinion, the purpose of tourism is to provide an outlet for rest and fun. Although tourists and residents both benefit from tourism development, if we examine their interests in further detail, it becomes apparent that there are significant differences in their needs and demands. Therefore, by resolving the aforementioned social, economic, and environmental issues and by identifying the needs and differences of each stakeholder, then it may be possible to formulate a balanced tourism development scheme that wins the approval of tourists and residents alike.

In each village, there are significant differences in stakeholder perception of economic-developmentrelated issues such as tourism plans, healthcare, consumer choices, tourism infrastructure, and professional ethics; social-development-related issues such as population structure, labor resources, and acceptance of tourism development; and environmental-development-related issues such as the development of water ecosystems, local commodity prices, and population decline.

In our opinion, tourist areas possess different types of tourist attractions, owing to the variations in their background and type, and the type of tourist attraction desired by each tourist also differs from one individual to another. Therefore, if the aforementioned social, economic, and environmental issues can be improved, so that the perceptions of the stakeholders towards each village can be made more consistent, it will then be possible for each village to formulate its own unique direction of development.

\subsection{Recommendations}

In the development of tourism and governmental policies, it is important to improve the level of service quality, develop specialty products, and cooperate with industry to increase consumer desire. The overall management and development of Sun Moon Lake should focus on development of the unique features of each village and the establishment of regional sightseeing tours, so as to improve the acceptance of tourism development among the residents and to encourage young people to return to their villages. Healthcare facilities should be improved to enhance quality of life. The number of public transportation access points in the villages should be increased, and the bicycle paths around the lake should be linked to the villages. Tourism fisheries and water activities should be developed, and artificially farmed native fingerlings should be introduced. The number of residents working in the aquaculture industry should be increased to promote environmental literacy and halt illegal releases of flora and fauna.

In our future research, we will extend this investigation towards the current state of development in other water conservation areas and study how different stakeholders perceive the balance point for development. In addition, we will also investigate how different ethnic groups and nationalities perceive the development of water conservation areas.

Author Contributions: H.-H.L. conceived, designed and wrote this paper. S.-S.L. and Y.-S.P. helped to check spelling, S.-T.Y. helped to check grammar of the article.

Acknowledgments: The authors especially thank the editors and anonymous referees for their kindly review and helpful comments.

Conflicts of Interest: All authors declare no conflict of interest. 


\section{References}

1. Ministry of Transportation and Communications. 2016 Annual Survey of Visitors Expenditure and Trends in Taiwan. 2017. Available online: http://admin.taiwan.net.tw/statistics/year.aspx?no=134 (accessed on 22 February 2018).

2. Cohen, C.; Regan, T. The Animal Rights Debate; Rowman \& Littlefield: Lanham, MD, USA, 2001; p. 336, ISBN 0-8476-9662-6.

3. Butler, R.W. The concept of a tourist area cycle of evolution: Implications for management of resources. Can. Geogr. 1980, 24, 5-12. [CrossRef]

4. Taylor, P. Respect for Nature: A Theory of Environmental Ethic. Environ. Ethics 1986, 3, 197-218. [CrossRef]

5. Ap, J.; Crompton, J.L. Developing and Testing a Tourism Impact Scale. J. Travel Res. 1998, 37, $120-130$. [CrossRef]

6. Gursoy, D.; Jurowski, C.; Uysal, M. Resident Attitudes: A structural modeling approach. Ann. Tour. Res. 2002, 20, 79-105. [CrossRef]

7. Perdue, R.R.; Long, P.T.; Allen, L. Resident support for tourism developments. Ann. Tour. Res. 1990, 14, 420-429. [CrossRef]

8. Ealey, A.J.; Snait, E.T.; Miller, G. Social impacts of tourism-A case study of BatE. UK Ann. Tour. Res. 2005, 32, 647-668. [CrossRef]

9. Ko, D.; Stewart, W.P. A structural equation model of residents' attitudes for tourism development. Tour. Manag. 2002, 23, 521-530. [CrossRef]

10. Ministry of Transportation and Communications. Visitors to the Principal Scenic Spots in Taiwan, 2016. 2017. Available online: http:/ / admin.taiwan.net.tw/statistics/year.aspx?no=134 (accessed on 22 February 2018).

11. Lankford, S.V.; Howard, D.R. Developing a Tourism Impacts Attitude Scale. Ann. Tour. Res. 1994, 21, 121-139. [CrossRef]

12. McCool, S.F.; Martin, S.R. Community Attachment and Attitudes toward Tourism Development. J. Travel Res. 1994, 32, 29-34. [CrossRef]

13. Cuieford, J.P. Fundamental Statistics in Psychology and Education; McGraw-Hill: New York, NY, USA, 1965; ISBN-10 0070251487.

14. Doxey, G.V. When enough's enough: The natives are restless in Old Niagara. Heritage Can. 1976, 2 , $26-27$. [CrossRef]

15. Nunkoo, R.; Ramkissoon, H. Modeling community support for a proposed integrated resort project. J. Sustain. Tour. 2010, 18, 257-277. [CrossRef]

16. Zaidan, E.; Kovacs, J.F. Resident attitudes towards tourists and tourism growth: A case study from the Middle East, Dubai in United Arab Emirates. Eur. J. Sustain. Dev. 2017, 6, 291-307. [CrossRef]

17. De Waal, F.B.M. Are We Smart Enough to Know How Smart Animals Are? W. W. Norton \& Company: London, UK, 2017.

18. Ka-shiang, L. Ring-Necked Bird Pinocha; Yuan-Liou Publishing: Taipei, Taiwan, 1991; p. 256, ISBN 9573212285.

19. Schreiber, R.L.; Diamond, A.W.; Peterson, R.T.; Cronkite, W. Save the Birds; Cambridge at the University Press: Lanham, MD, USA, 1987; p. 384, ISBN-10 0395511720.

20. Carmichael, B.A.; Peppard, D.M., Jr.; Boudreau, F.A. Megaresort on my doorstep: Local resident attitudes toward Foxwoods casino and casino gambling on nearby Indian reservation land. J. Travel Res. 1996, 34, 9-16. [CrossRef]

21. Lawson, R.W.; Williams, J.; Young, T.; Cossens, J. A comparison of residents' attitudes towards tourism in 10 New Zealand destinations. Tour. Manag. 1998, 19, 247-256. [CrossRef]

22. Lankford, S.V. Attitudes and perceptions toward tourism and rural regional development. J. Travel Res. 1994, 32, 35-43. [CrossRef]

23. Jorge, P.E.; Pinto, B.V. Olfactory information from the path is relevant to the homing process of adult pigeons. Behav. Ecol. Sociobiol. 2017, 72, 5. [CrossRef]

24. Jurowski, C.; Uysal, M.; Williams, D. A theoretical analysis of host community resident reactions to tourism development. J. Travel Res. 1997, 36, 3-11. [CrossRef]

25. Husbands, W. Social status and perception of tourism in Zambia. Ann. Tour. Res. 1989, 16, $237-253$. [CrossRef] 
26. Campón-Cerro, A.M.; Folgado-Fernández, J.A.; Hernández-Mogollón, J.M. Rural Destination Development Based on Olive Oil Tourism: The Impact of Residents' Community Attachment and Quality of Life on Their Support for Tourism Development. Sustainability 2017, 9, 1624. [CrossRef]

27. Keogh, B. Public participation in community tourism planning. Ann. Tour. Res. 1990, 17, 449-465. [CrossRef]

28. Otto, J.E.; Ritchie, J.R.B. The service experience in tourism. Tour. Manag. 1996, 17, 165-174. [CrossRef]

29. Belisle, F.J.; Hoy, D.R. The Perceived Impact of Tourism by Residents: A Case Study in Santa Marta, Colombia. Ann. Tour. Res. 1980, 7, 83-101. [CrossRef]

30. Zhang, A.; Zhong, L.; Xu, Y.; Wang, H.; Dang, L. Tourists' Perception of Haze Pollution and the Potential Impacts on Travel: Reshaping the Features of Tourism Seasonality in Beijing, China. Sustainability 2015, 7, 2397-2414. [CrossRef]

31. Tsai, K.-T.; Lin, T.-P.; Lin, Y.-H.; Tung, C.-H.; Chiu, Y.-T. The Carbon Impact of International Tourists to an Island Country. Sustainability 2018, 10, 1386. [CrossRef]

32. Ryan, C.; Huyton, J. Balanda Tourists and Aboriginal People. Ann. Tour. Res. 2002, 29, 631-647. [CrossRef]

33. Strauss, A.; Corbin, J.M. Basics of Qualitative Research: Grounded Theory Procedures and Techniques; Sage: Newbury Park, CA, USA, 1990; p. 400, ISBN-13 978-1412906449.

34. Strauss, A.; Corbin, J.M. Basics of Qualitative Research: Grounded Theory Procedures and Techniques, 2nd ed.; Sage: Thousand Oaks, CA, USA, 1998; p. 336. ISSN 1049-7323.

35. Janesick, V.J. The choreography of qualitative research design: Minuets, improvisations, and crystallization. In Handbook of Qualitative Research; Denzin, N.K., Lincoln, Y.S., Eds.; Sage: Thousand Oaks, CA, USA, 1998; pp. 379-399.

36. Tuomaala, M.S.; Kurki, P.Å.; Rekiaro, M.; Paavilainen, E. Coping Experiences: A Pathway towards Different Coping Orientations Four and Twelve Months after Myocardial Infarction-A Grounded Theory Approach. Nurs. Res. Pract. 2012, 2012, 674783. [CrossRef]

37. Ajzen, I. The theory of planned behavior. Organ. Behav. Hum. Decis. Process. 1991, 50, 179-211. [CrossRef]

38. Teye, V.; Sonmez, S.F.; Sirakaya, E. Residents' Attitudes towards Tourism Development. Ann. Tour. Res. 2002, 29, 668-688. [CrossRef]

39. Tai-Yi Associates. Comprehensive Outline Plan for the Tourism Development of Sun Moon Lake National Scenic Area: Final Report; Sun Moon Lake National Scenic Area Administration: Nantou, Taiwan, 2014.

40. Haeckel, E. Ueber die Crambessiden, eine neue Meduse-Familie aus der Rhizostomeengruppe. Zeitschrift Für Wissenschaftliche Zoologie 1869, 19, 509-537.

41. Streubert-Speziale, H.J.; Carpenter, D.R. Qualitative Research in Nursing: Advancing the Human Imperative; Lippincott Williams and Wilkins: London, UK, 2003; p. 470, ISBN-10 0781796008.

42. Thurow, L.C. The Future of Capitalism: How Today's Economic Forces Will Shape Tomorrow's World; Penguin Books: New York, NY, USA, 1998; p. 400, ISBN-10 0140263284. 